\title{
Representasi Nasionalisme sebagai Personal Branding Suporter Bulutangkis Haryanto di Media Sosial
}

\author{
Themotia Titi Widaningsih ${ }^{1}$, Budi Santoso ${ }^{2}$, Hifni Ali Fahmi ${ }^{3}$ \\ 1,2,3 Program Magister Ilmu Komunikasi, Sekolah Pascasarjana Universitas Sahid Jakarta \\ J1 .Jend.Sudirman 56 Jakarta Pusat 10220, Indonesia \\ titi_widaningsih@usahid.ac.id ${ }^{1 *}$, budiusahid27@gmail.com², alifahmi21@yahoo.com ${ }^{3}$ \\ *Corresponding author
}

\begin{abstract}
Haryanto, Indonesian badminton supporters, always wears red and white attributes when attending badminton matches. The red and white attribute Harjanto wore is to show nationalism. The red and white attribute makes Harjanto different from other supporters and is easily recognized. The red and white attributes that Haryanto always wear unconsciously have shaped personal branding. The research objective is to analyze Haryanto with red and white attributes as a representation of nationalism in forming personal branding. The research was conducted using a qualitative descriptive method. The research object was 6 photos on social media showing Haryanto supporting the Indonesian badminton team. The research subject as well as the key informant was Haryanto. Data collection was carried out by document analysis and in-depth interviews. Text analysis was performed using Kress and Van Leeuwen's social semiotic analysis with Montoya and Vandehey's personal branding elements. The results of social semiotic analysis of 6 photos, 3 photos representing narrative and 3 photos representing conceptual. The results of the analysis using eight elements of Peter Montoya's personal branding formation. Haryanto's nationalist representation through the red and white attribute, unwittingly forming a personal brand. The substance of this research is to contribute in the form of recommendations theoretically emphasizing that representations can build personal branding by building representations through symbols adapted to the elements of Montoya 's personal branding formation. Keywords: Supporters; Social Semiotics; Representation; Nationalism; Personal Branding
\end{abstract}

\begin{abstract}
Abstrak
Haryanto suporter bulutangkis Indonesia selalu mengenakan atribut merah putih saat hadir pada pertandingan bulutangkis. Atribut merah putih yang dikenakan Harjanto untuk menunjukkan nasionalisme. Atribut merah putih membuat Harjanto berbeda dengan supporter lain dan mudah dikenali. Atribut merah putih yang selalu ditampilkan Harjanto tanpa disadari telah membentuk personal branding. Tujuan penelitian untuk menganalisis Haryanto dengan atribut merah putih sebagai representasi nasionalisme dalam membentuk personal branding. Penelitian dilakukan menggunakan metode deskriptif kualitatif. Objek penelitian 6 foto di media sosial yang menampilkan Haryanto sedang mendukung tim bulutangkis Indonesia. Subjek penelitian sekaligus key informan adalah Haryanto. Pengumpulan data dilakukan dengan analisis dokumen dan wawancara mendalam. Analisis teks dilakukan menggunakan analisa semiotika sosial Kress dan Van Leeuwen dengan elemen personal branding Montoya dan Vandehey. Hasil analisis semiotika sosial terhadap 6 foto, 3 foto merepresentasikan naratif dan 3 foto merepresentasikan konseptual. Hasil analisis menggunakan delapan elemen pembentukan personal branding Peter Montoya, representasi nasionalis Haryanto melalui atribut merah putih tanpa disadari telah membentuk personal brand. Substansi penelitian ini memberikan kontribusi berupa rekomendasi secara teoritis mempertegas bahwa representasi dapat membangun personal branding dengan membangun representasi melalui simbol simbol yang disesuaikan dengan elemen pembentukan personal branding Montoya. Kata kunci: Suporter; Semiotika Sosial; Representasi; Nasionalisme; Personal Branding.
\end{abstract}

\section{Pendahuluan}

Pada mulanya olahraga hanya menjadi salah satu kebutuhan manusia untuk menjaga tubuh tetap sehat dan bugar. Kemudian Olahraga mengalami perkembangan. Tidak hanya sebagai kebutuhan untuk menjaga kesehatan tetapi olah raga dijadian sebuah hiburan atau tontonan.
Salah satu cabang olahraga yang populer di kawasan Asia adalah bulutangkis (Supriyanto Nugroho A \& Rasyid Ainur, 2018). Bulutangkis mulai populer di dunia sejak tahun 1992 saat Olimpiade Barcelona. Pada Olimpiade Barcelona olahraga bulutangkis mulai 
dimasukkan sebagai salah satu cabang olahraga yang dipertandingkan dalam olimpiade. (Chint et al., 1995; Cabello \& Gonzalez, 2003). Bulutangkis juga sebagai salah satu cabang olahraga yang populer dan digemari oleh masyarakat Indonesia, mulai dari anakanak sampai orang tua, laki-laki maupun perempuan, masyarakat bawah, menengah dan atas. Setiap orang bisa bermain bulutangkis tanpa memandang status sosial.

Bulutangkis merupakan permainan olahraga yang sederhana. Bulutangkis dimainkan cukup dengan menggunakan raket sebagai alat pemukul dan shuttlecock sebagai obyek pemukul. Bulutangkis dapat dilakukan di dalam maupun di luar ruangan. Olahraga bulutangkis dilakukan dengan cara satu orang melawan satu orang (tunggal) atau dua orang melawan dua orang (ganda).

Bulutangkis cepat menyebar ke berbagai pelosok daerah di Indonesia, bahkan di daerah perkotaan lapangan bulutangkis terdapat hampir di setiap rukun warga (RW) (Dinata, 2004). Bulutangkis menjadi salah satu cabang olahraga yang sangat digemari dan menjadi andalan masyarakat Indonesia (Wijaya I Made K., 2018). Melalui bulutangkis, Indonesia dikenal di dunia internasional dengan prestasi yang atlet-atlet Indonesia.

Pertandingan olahraga sebagai sebuah tontotan tidak bisa dipisahkan dengan suporter. Suporter ialah satu individu atau lebih yang memberikan dukungan kepada salah satu pihak dalam sebuah pertandingan. Suporter adalah salah satu elemen penting dalam pertandingan. Keberadaan suporter menjadi bagian yang tidak terpisahkan dari olahraga sebagai sebuah industri (Junaedi F., 2012).

Suporter secara tidak langsung membantu para atlet mencapai kesuksesan dengan pemberian dukungan yang tiada henti. Tanpa suporter pertandingan olahraga tidak akan ramai, menarik, dan hambar. Kehadiran suporter membuat atlet mendapat dukungan dan semangat terus menerus. Suporter bersama para pemain, official, dan perangkat pertandingan menciptakan suasana sedemikian rupa seh- ingga bisa meningkatkan daya juang pemain yang didukung bahkan melemahkan mental lawan (Ridyawanti, 2008 dalam Hapsari \& Wibowo 2015). Suporter Indonesia bisa dikatakan sebagai suporter yang sangat fanatik.

Bulutangkis sebagai olahraga terpopuler kedua setelah sepakbola, tidak menyurutkan masyarakat Indonesia untuk selalu mendukung dengan menjadi suporter ketika ada pertandingan Bulutangkis (Indrayani H., Sunarto, 2019). Gaya khas dari suporter bulutangkis Indonesia yang sudah terkenal hingga luar negeri adalah gemuruh, bising serta teriakan yang keras. Tak jarang suporter melakukan tindakan bernyanyi, memukul balon hingga intimidasi terhadap lawan. Salah satu intimidasi yang masih sering dilakukan oleh suporter bulutangkis Indonesia adalah teriakan khas 'Eeeeaaaa, Huuuuuu, Eeaaaaaa, Huuuuu'. Teriakan khas itu sering terdengar pada turnamen bulutangkis yang digelar di Indonesia.

Suporter bulutangkis di Indonesia memang sangat militan. Gemuruh teriakan dan yel-yel memberi semangat pemain. Seringkali pemain lawanpunkonsentrasinyaterpecahkarenateriakan suporter Indonesia. Sorak-sorai "Indonesia" menggema, memenuhi arena pertandingan. Para suporter bulutangkis Indonesia juga sering meneriakkan nama pemain yang menjadi idola seperti "Kevin, Kevin". John Duerden menyatakan suporter Indonesia merupakan suporter terbaik di dunia. (Hasan Zainal, 2018).

Dukungan yang luar biasa dari suporter bulutangkis Indonesia menjadikan kompetisi Indonesia Open sebagai turnamen terbaik dunia oleh BWF (Badminton World Federation) setelah All England. Salah satu indikator penilaiannya adalah jumlah penonton di setiap babak. Antusiasme yang tinggi dari penggemar bulutangkis Indonesia menyebabkan tiket penjualan selalu habis terjual (Ibrahim Herry, 2020).

Kompetisi bulutangkis di Indonesia seringkali dijuluki neraka bagi pemain lawan tim Indonesia. Fanatisme suporter yang hadir ditandai dengan 
atribut yang dikenakan demi mendukung atlet bulutangkis Indonesia. Gendang, terompet, dan drum kecil, seolah menjadi barang wajib bagi para suporter ketika mendukung pemain Indonesia yang menjadi kesayangan dan kebanggaannya.

Dukungan yang diberikan oleh suporter bulutangkis Indonesia merupakan wujud nasionalisme dan kecintaannya pada Indonesia. Salah satu tindakan yang dilakukan adalah memberikan dukungan langsung di stadion saat pertandingan dengan menggunakan berbagai atribut merah putih dan meneriakkan kata "Indonesia" berulang kali, tindakan ini sering dianggap noisy supporter. Teriakan hingga intimidasi yang dilakukan oleh suporter sah-sah asalkan tidak menyinggung SARA (Suku, Agama, Ras, dan Antar golongan). Tidak ada aturan khusus mengenai dukungan supporter dalam olahraga bulutangkis. Suporter dibebaskan untuk mendukung dengan cara apapun, berbeda dengan tenis, golf dan billiard yang memiliki aturan mengikat untuk suporter.

Pada tiga cabang olahraga tenis, golf dan biliar, suporter tidak bisa seenaknya meneriakan yel-yel dan teriakan yang bisa mengganggu jalannya pertandingan. Atlet tenis, golf dan billiard membutuhkan konsentrasi penuh ketika berlaga. Pada olahraga tenis, suporter hanya diperkenankan tepuk tangan saat pemain dapat poin. Hal ini berbanding terbalik dengan pertandingan bulutangkis, khususnya di Indonesia. Pada beberapa negara di Eropa, penonton bulutangkis terlihat seperti suporter tenis yang tidak berisik saat pertandingan sedang berlangsung. Bentuk dukungan yang diberikan oleh suporter bulutangkis Indonesia sah-sah saja dilakukan, karena tidak ada aturan khusus yang mengatur.

Bulutangkis sebagai olahraga yang disukai masyarakat Indonesia, memiliki banyak suporter fanatik yang senantiasa mendukung dalam setiap pertandingan. Salah satu suporter bulutangkis Indonesia yang sudah lebih dari tiga dasawarsa mendukung atlet bulutangkis Indonesia adalah Hariyanto atau yang biasa disebut oleh suporter lain dengan Pak Yanto. Haryanto adalah orang asli Indonesia yang lahir di Pamekasan. Namun sejak tahun 1980 Haryanto pindah ke Malaysia. Dirinya yang masih menjadi Warga Negara Indonesia tidak mau menanggalkan kewarganegaraannya karena kecintaan kepada Indonesia yang tidak bisa digantikan oleh apapun.

Haryanto sebagai suporter bulutangkis Indonesia selalu tampil dengan ciri khasnya tersendiri dalam setiap pertandingan bulutangkis. Haryanto selalu datang mengenakan atribut berwarna merah putih, yang merupakan warna benderanegara Indonesia. Atributtersebut dipakai oleh Haryanto untuk menunjukkan kecintaannya kepada Indonesia dan sebagai bentuk dukungan kepada para atlet bulutangkis yang bertanding.

Haryanto selalu tampil dengan atribut merah putih dan ID card sebagai identitas. ID card merupakan free pass yang dibuat khusus untuk Haryanto agar bebas masuk ke dalam setiap pertandingan yang ingin didukungnya. ID card didapatkan sebagai wujud apresiasi atas loyalitas Haryanto dalam mendukung tim bulutangkis yang tidak pernah meninggalkan atributnya.

Penggunaan atribut yang bertemakan Indonesia menjadi pembeda dengan suporter lainnya. Haryanto mudah dikenali dibanding dengan suporter-suporter lain. Bukan hanya penampilannya yang nyentrik, Haryanto sering menjadi leader bagi suporter lain dalam mendukung atlet-atlet Indonesia. Saat berlangsungnya kejuaraan Indonesia Master 2020 Haryanto dikenal dengan sebutan panglima suporter bulutangkis Indonesia. Haryanto yang membuat satu Istora meriah dengan kehadirannya yang memberikan yel-yel kepada para atlet dan mengajak para suporter lain untuk membuat tarian ombak, agar para atlet yang bertanding lebih bersemangat lagi (Hasyim, Irsyam, 2020).

Haryanto menunjukkan nasionalisme dirinya dengan mengenakan atribut merah putih pada setiap pertandingan bulutangkis yang dihadirinya. Apa yang dilakukan Haryanto dapat dikatakan sebagai representasi 
nasionalisme. Rasa cinta Haryanto terhadap Indonesia juga dibuktikan dengan berkeliling ke beberapa negara Asia bahkan ke Eropa tempat diselenggarakan kejuaraan bulutangkis dengan menggunakan biaya sendiri.

Haryanto hampir tidak pernah absen memberikan dukungan kepada atlet-atlet Indonesia disetiap gelaran kejuaran Indonesia Open di Istora Senayan Jakarta maupun kejuaraan bulutangkis di berbagai negara. Memakai atribut merah putih yang wajib dikenakan ketika menghadiri pertandingan bulutangkis, Haryanto selalu menjadi pusat perhatian sesama suporter dan penonton lainnya. Kecintaan Haryanto kepada Indonesia seolah-olah terwakili melalui atribut yang bernuansa merah putih dalam setiap kesempatan mendukung atlet-atlet Indonesia.

Penampilan Haryanto yang merepresentasikan nasionalisme melalui atribut suporter bulutangkis yang digunakannya untuk mendukung setiap pertandingan bulutangkis, tanpa disadari oleh Haryanto telah menjadi sarana dalam proses pembentukan personal branding dirinya.

Penelitian Butar Butar C.R, dan Ali Dini S.F. (2017) tentang strategi personal branding selegram menyatakan bahwa strategi personal branding terbentuk jika individu memiliki nilai, karakter dan moral yang baik. Fokus pada satu bidang, konsisten, memiliki relevansi dan visibilitas. Mendapat pengakuan dan tetap menjaga eksistensinya.

Penelitian Salam Oryza D. tentang personal branding digital natives di Instagram menunjukan personal branding terbentuk jika seorang mampu memberikan kesan karakter diri yang berbeda yang dapat dilihat dengan jelas oleh pengikutya. Berani mengeksplorasi dirinya sehinga dapat menemukan hal-hal yang membuatnya unik, sehingga mendapat perhatian pengikutnya. Penampilan, kosistensi, keteguhan dan nama baik bersinergis membangun personal branding.
Penelitian sebelumnya mengkaji personal branding yang dilakukan seseorang yang aktif di media sosial. Media sosial sebagai sarana membangun personal branding karena memiliki kredibilitas dan kekuatan dalam membangun persepsi positif dibenak followers-nya. Personal branding dilakukan untuk membangun citra diri yang positif dan meningkatkan jumlah followers. Penampilan Haryanto pada setiap pertandingan bulutangkis dengan atribut merah putih bukan untuk membentuk personal branding, namun tanpa sengaja telah membentuk personal branding.

\section{Teori Representasi}

Representasi adalah kemampuan untuk menggambarkan. Representasi berperan penting karena budaya dibentuk melalui makna dan bahasa. bahasa adalah salah satu bentuk dari simbol atau bentuk representasi (Hall, 2005). Representasi adalah suatu proses untuk memproduksi makna, dari konsep yang ada dalam pikiran melalui Bahasa (Hall, 2003). Representasi bekerja melalui system representasi. Sistem representasi memiliki dua konsep penting yaitu konsep dalam pikiran dan bahasa, keduanya saling berelasi. Sesuatu konsep membuat pengetahuan tentang suatu makna.

Teori representasi menyatakan makna dikontruksi melalui bahasa. Representasi sebagai suatu proses produksi makna dari konsep yang ada dalam pikiran melalui Bahasa. Konsep dan tanda menjadi bagian penting dalam proses kontruksi makna. Proses produksi makna dapat dilakukan karena adanya system representasi.

Representasi sebagai konstruksi sosial mengharuskan eksplorasi pembentukan makna tekstual dan menghendaki penyelidikan tentang cara dihasilkannya makna pada beragam konteks. Representasi dan makna budaya memiliki materialitas tertentu (Chris Barker 2008). Representasi diproduksi, ditampilkan, digunakan dan dipahami dalam konteks sosial tertentu. Representasi sebagai sebuah pemahaman yang ingin diberikan atas suatu 
hal. Representasi juga dapat dilihat secara berbeda, tergantung dari sudut mana seseorang melihatnya. Representasi juga dapat dipengaruhi oleh pengetahuan yang dimiliki oleh seseorang. Representasi kerap menjadi sebuah stereotip atau bisa dikatakan sebagai "cap" yang diberikan atas seseorang (Chris Barker, 2008).

Penampilan Haryanto saat mendatangi pertandingan bulutangkis merepresentasikan nasionalisme kepada negaranya Indonesia, dengan mengenakan atributberwarna merah putih seperti bendera Indonesia. Representasi tersebut membuat dirinya mudah dikenali ketika hadir pada pertandingan. Tidak hanya pertandingan bulutangkis di dalam negeri tapi juga di luar negeri tidak pernah luput dari kehadiran Haryanto yang datang lengkap dengan atributnya.

\section{Nasionalisme}

Nasionalismemerupakan sebuahpemahaman yang menyatakan kesetiaan tertinggi individu harus diserahkan kepada negara. Perasaan sangat mendalam akan suatu ikatan yang erat dengan tanah tumpah darahnya, dengan tradisitradisi setempat dan penguasa-penguasa resmi di daerahnya selalu ada di sepanjang sejarah dan kekuatan yang berbeda-beda (Khon, 1984).

Nasionalisme merupakan suatu paham yang mengambarkan betapa besarnya rasa cinta terhadap bangsa dan negara, dan rela berkorban untuk bangsanya (Agung Iskandar, 2014). Nilai-nilai nasionalisme tersebut antara lain (1) Mencintai tanah air dan bangsa, bangga berbangsa dan bernegara Indonesia. (2) Rela Berkorban mengutamakan kepentingan bersama daripada kepentingan diri sendiri. Mempunyai kesetiaan terhadap bangsa dan Negara dengan memberi perhatian pada kepentingan umum. (3) Adil Kepada Negara membagi tugas sesuai dengan kemampuan masing- masing. (4) Pengabdian kepada Negara menyediakan diri untuk membantu negara. Merasa terpanggil untuk berbuat sesuatu bila melihat ada yang kurang sesuai. (5) Rasa Memiliki Budaya Bangsa turut melestarikan dan mengembangkan budaya bangsa sendiri. (6) Kesetiaan pada Negara menepati janji untuk mendukung kegiatan masyarakat di sekitarnya. Melaksanakan apa yang telah menjadi tugas dan kewajibannya.

Nasionalisme lebih merupakan sebuah fenomena budaya daripada fenomena politik karena dia berakar pada etnisitas dan budaya (Hutchinson (2000:34). Jika nasionalisme bertransformasi menjadi gerakan politik, hal tersebut bersifat superfisial. Gerakan-gerakan politik nasionalisme pada akhirnya dilandasi oleh motivasi budaya, khususnya saat terjadi krisis identitas kebudayaan. Dengan menjunjung tinggi semangat nasionalisme, kecintaan masyarakat akan bangsa dan negara sendiri akan lebih tinggi. Pengaruh budaya asing dapat ditangkis dengan memiliki nasionalisme yang kuat. Kekuatan nasionalisme yang dimiliki seseorang dapat ditularkan kepada orang lain agar lebih menghargai bangsa dan negaranya.

Haryanto memiliki ikatan yang kuat dengan Indonesia, sehingga menumbuhkan rasa nasionalis di dalam dirinya. Nasionalisme yang dipegang Haryanto tidak hanya disimpan untuk dirinya sendiri. Nasionalismenya ditularkan kepada orang lain dengan cara mengenakan atribut suporter bulutangkis yang bertemakan merah putih. Merah putih representasi Indonesia, agar yang melihatnya dapat ikut merasakan nasionalisme yang dimiliki oleh Hariyanto.

\section{Semiotika Sosial}

Semiotika sosial adalah salah satu metode yang biasa digunakan untuk menganalisis bahasa gambar. Selain semiotika sosial, terdapat metode lain seperti analisis isi kuantitatif, photo voice, multimodalitas, dan sebagainya (Eriyanto, 2019). Kata kunci semiotika adalah tanda (sign) dan kode (Kress dalam Eriyanto, 2019). Sementara pada semiotika sosial, kata kuncinya adalah pengunaan atau pembuatan tanda (sign-making). Semiotika sosial berpandangan bahwa manusia pada dasarnya adalah pembuat tanda (sign-maker). 
Pada semiotik sosial terdapat tiga metafungsi yang sering dipakai dalam melakukan penelitian dengan metode semiotika sosial, yaitu: 1) Representasi: Pada semiotika sosial, representasi dibagi menjadi dua, yaitu: a) Representasi Naratif: gambar diandaikan mempunyai struktur transitif, dimana didalam gambar tersebut terdapat aktor, proses (kegiatan atau tindakan); dan b) Representasi Konseptual: gambar menyampaikan suatu gagasan (apa yang ingin ditampilkan) dalam bentuk konseptual. Pada representasi konseptual, gambar didefinisikan menganalsis atau mengklasisfikasikan orang, benda atau sesuatu.

2) Interaksi: fungsi interpersonal dalam bahasa gambar dikenal sebagai interaksi. Gambar tidak hanya menampilkan gagasan atau ide yang ingin disampaikan kepada khalayak, tetapi juga interaksi dengan khalayak (Eriyanto, 2019). 3) Komposisional: gambar mengandung fungsi komposisional. Gambar menyatukan berbagai elemen sehingga membentuk satu kesatuan, dan ketika diterima oleh orang khalayak gambar tersebut mempunyai arti (makna). Fungsi komposisional ini sama dengan tekstual dalam bahasa tulis.

Nasionalisme merupakan satu paham yang menyatakan kesetian tertinggi individu harus diserahkankepadanegaradanbangsanya.Perasaan sangat mendalam akan suatu ikatan yang erat dengan tanah tumpah darahnya, dengan tradisitradisi setempat dan penguasa-penguasa resmi di daerahnya selalu ada di sepanjang sejarah dan kekuatan yang berbeda-beda (Khon, 1984: 11).

Haryanto memiliki ikatan yang kuat dengan Indonesia sehingga menumbuhkan rasa nasionalis di dalam dirinya. Nasionalisme yang dimiliki Haryanto tidak hanya disimpan untuk dirinya sendiri. Haryanto mengekspreskan nasionalisme dengan cara mengenakan atribut suporter bulutangkis yang bertemakan merah putih yang melambangkan Indonesia, agar orang lain yang melihat dapat ikut merasakan nasionalisme yang dimiliki oleh Hariyanto.
Terdapat tiga elemen yang dapat membangun personal branding. Elemen branding harus saling terintegrasi dan dibangun bersamaan (Montoya \& Vandehey, 2008 ). Tiga elemen utama personal branding yaitu: 1) You, atau dengan kata lain orang itu sendiri. Seseorang dapat membentuk sebuah personal branding melalui sebuah polesan dan metode komunikasi yang disusun dengan baik; 2) Promise, personal branding adalah sebuah janji, sebuah tanggungjawab untuk memenuhi harapan yang timbul pada masyarakat akibat dari personal branding itu sendiri; dan 3) Relationship, personal branding yang baik mampu menciptakan suatu relasi yang baik dengan klien. Semakin banyak atribut yang dapat diterima oleh kalayak dan semakin tingginya tingkat kekuasaan seseorang, menunjukkan semakin baik tingkat relasi personal branding tersebut.

Konsep pembentukan personal branding sebagai pondasi dari personal brand yang kuat. Ada delapan konsep pembentukan personal branding menurut Montoya (2002) yaitu: 1) Spesialisasi (The law of specialization): ciri khas dari sebuah personal brand yang hebat adalah ketepatan pada sebuah spesialisasi, terkonsentrasi hanya pada sebuah kekuatan, keahlian, atau pencapaian tertentu; 2) Kepemimpinan (The Law of Leadership): personal brand dilengkapi dengan sosok pemimpin yang dapat memutuskan sesuatu dalam suasana penuh ketidakpastian dan memberikan suatu arahan yang jelas; 3) Kepribadian (The Law of Personality): personal brand yang hebat didasari pada sosok kepribadian yang apa adanya dan hadir dengan ketidaksempurnaan. Konsep ini menghapuskan beberapa tekanan pada konsep kepemimpinan (the law of leadership). Seorang harus memiliki kepribadian yang baik, namun tidak harus sempurna; 4) Perbedaan (The Law of Distictiveness): personal brand yang efektif harus ditampilkan dengan cara yang berbeda dari yang lainnya. Diferensiasi diperlukan supaya membedakan antara satu dengan lainnya. Selain 
itu dengan perbedaan seorang akan lebih dikenal oleh khalayak; 5) Terlihat (The Law of Visibility): personal brand harus dilihat secara konsisten dan terus menerus sampai personal brand seseorang dikenal. Maka visibility lebih penting dariabilility. Supaya visible seseorang perlu mempromosikan dirinya dan menggunakan setiap kesempatan untuk membuat dirinya terlihat; 6) Kesatuan (The Law of Unity): Kehidupan pribadi yang berada di balik personal brand harus sejalan dengan etika moral dan sikap yang telah ditentukan dari brand tersebut. Kehidupan pribadi selayaknya menjadi cerminan dan citra yang diinginkan dalam personal brand; 7) Keteguhan (The Law of Persistence): personal brand tidak bisa terjadi secara instan, membutuhkan waktu untuk tumbuh. Selama proses tersebut berjalan, penting untuk selalu memperhatikan tiap tahapan dan trend yang terjadi; dan 8) Nama Baik (The Law of Goodwill): personal brand akan memberikan hasil yang baik dan bertahan lebih lama, jika seseorang dibelakangnya dipersepsikan dengan citra yang positif. Seseorang tersebut harus diasosiasikan dengan sebuah nilai atau ide yang diakui secara umum positif dan bermanfaat.

Tujuan penelitian ini untuk menganalisis Haryanto dengan atribut merah sebagai representasi nasionalisme dalam membentuk personal branding. Analisis dilakukan dengan menggunakan analisis semiotika sosial Kress dan Van Leeuwen, dengan elemen personal branding Peter Montoya.

\section{Metode Penelitian}

Penelitian ini menggunakan paradigma konstruktivisme. Pada paradigma konstruktivisme realitas merupakan konstruksi sosial dan kebenaran suatu realitas bersifat relatif berlaku sesuai konteks spesifik yang dinilai relevan oleh pelaku sosial. Penelitian merupakan produk interaksi antara peneliti dengan yang diteliti. Hasil penelitian merupakan refleksi otentik dari realitas dihayati oleh para pelaku sosial dimana nilai, etika dan pilihan moral merupakan sebuah satu kesatuan (Salim, 2006). Realitas sosial yang diamati tidak dapat digeneralisasikan pada semua orang.

Metode penelitian yang digunakan adalah deskriptif kualitatif. Penelitian deskriptif bertujuan untuk: (1) mengumpulkan informasi aktual secara rinci yang melukiskan gejala yang ada, (2) mengindentifikasi masalah atau memeriksa kondisi dan praktik-praktik yang berlaku, (3) membuat perbandingan atau evaluasi, (4) menentukan apa yang dilakukan orang lain dalam menghadapi masalah yang sama dan belajar dari pengalaman untuk menetapkan rencana dan keputusan pada waktu yang akan datang (Rakhmat, 2009). Penelitian yang bermaksud untuk memahami fenomena tentang apa yang dialami oleh subjek penelitian. (Moleong, 2012). Pendekatan kualitatif sebagai prosedur penelitian yang menghasilkan data dekriptif berupa kata-kata tertulis ataupun lisan dari orang-orang dan perilaku yang dapat diamati (Yogi Gian P. Ruchiat A., Setianti Y., 2016).

Objek penelitian adalah unggahan foto-foto di media sosial yang menampilkan Haryanto yang sedang mendukung pemain bulutangkis Indonesia yang sedang bertanding. Foto penampilan Haryanto dilengkapi dengan berbagai atribut yang bernuansa merah putih. Unggahan foto Haryanto di media sosial yang diteliti sebanyak 6 foto.

Subjek penelitian sekaligus sebagai informan utama penelitian (key informan) adalah Haryanto. Haryanto merupakan suporter bulutangkis Indonesia yang selalu selalu mendukung pemain bulutangkis Indonesia saat bertanding dan menggunakan atribut supporter yang bernuansa merah dan putih.

Metode pengumpulan data dilakukan dengan wawancara mendalam (indepth interview) dan analisis dokumen digunakan bersama-sama (Mulyana, 2010). Metode pengumpulan data tersebut lebih unggul karena memungkinkan peneliti memadukan simbol dan interaksi. Mengambil peran yang diamati memasuki 


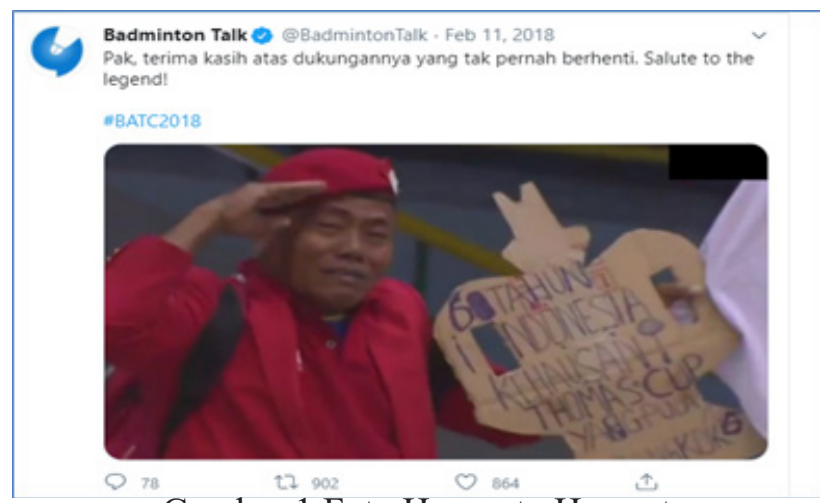

Gambar 1 Foto Haryanto Hormat

Dengan Memegang Duplikat Piala Asia Sumber: Twitter Badminton Talk(@BadmintonTalk) (2018)

dunia sosial subyek penelitian dan mengaitkan simbol-simbol dengan dunia sosial, merekam berbagai situasi (Denzin, 2009). Data merupakan sesuatu yang dikumpulkan peneliti berupa fakta empiris yang digunakan untuk memecahkan masalah atau menjawab pertanyaan penelitian.

Data dapat berbentuk angka, huruf, gambar, suara, suatu keadaan, atau simbol-simbol lainnya (Siyoto dan Sodik (2015). Data primer diperoleh dari wawancara mendalam dengan key informant dan unggahan foto di media sosial yang menampilkan Haryanto yang sedang mendukung pertandingan bulutangkis pemain Indonesia. Data sekunder dikumpulkan dari bahan Pustaka, pengamatan pertandingan bulutangkis. Data sekunder ini sifatnya sebagai data penunjang dan penguat dari data primer (Bungin:2008).

Metode analisis yang digunakan adalah metode semiotika sosial Kress dan Van Leeuwen. Semiotika sosial pada awalnya hanya digunakan untuk analisis bahasa (teks) tertulis. Prinsipprinsip dasar semiotika sosial tidak hanya berlaku pada teks tertulis, tetapi juga teks gambar (visual). Analisa semiotika sosial sesuai digunakan untuk menganalisa foto foto Haryanto di media sosial.

Semiotika sosial tidak hanya berhenti pada pertanyaan mengapa tanda tersebut yang dipilih, dan apa implikasinya bagi makna

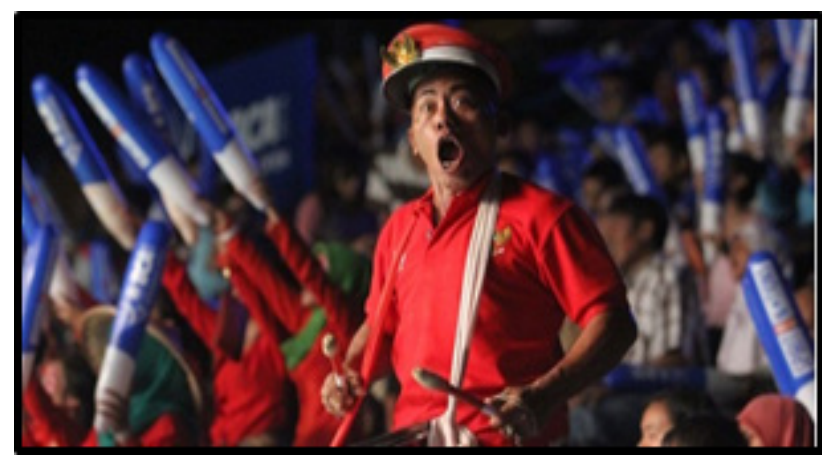

Gambar 2 Foto Haryanto Sedang Menabuh Genderang

Sumber :https://www.idntimes.com/hype/viral/ adiputra/10-potret-pak-yanto-suporter-bulu-tangkislegendaris-selama-38-tahun/10

yang ditimbulkan (Eriyanto, 2019). Pengguna tanda mempunyai pilihan sumber semiotika yang sangat banyak, bahkan tidak terbatas.

Analisa semiotika sosial dilakukan untuk mengidentifikasi sumber semiotika yang dipakai. Kedua, untuk mempertanyakan secara kritis, mengapa pilihan sumber semiotika ini yang dipilih. Analisa semiotika sosial dilakukan tidak berhenti pada menemukan dan mendeskripsikan sumber semiotika dalam gambar tetapi juga mempertanyakan secara kritis mengapa sumber semiotika tertentu yang diambil oleh pembuat gambar bapak Haryanto.

Analisis semiotika sosial dilakukan dengan melihat dua representasi, yaitu representasi naratif dan representasi konseptual. Pada representasi naratif gambar diandaikan mempunyai struktur transitif, dimana didalam gambar terdapat aktor, proses (kegiatan atau tindakan) dan sasaran. Pada representasi konseptual, gambar mendefinisikan atau mengklasifikasikan orang, benda atau sesuatu (Eriyanto, 2019). Cara membedakan antara representasi naratif dan representasi konseptual dilakukan dengan melihat ada atau tidaknya vektor pada gambar.

Data penelitian diuji keabsahnnya untuk menyatakan bahwa penelitian kredibel dan dapat dipercaya. Uji keabsahan data yang 


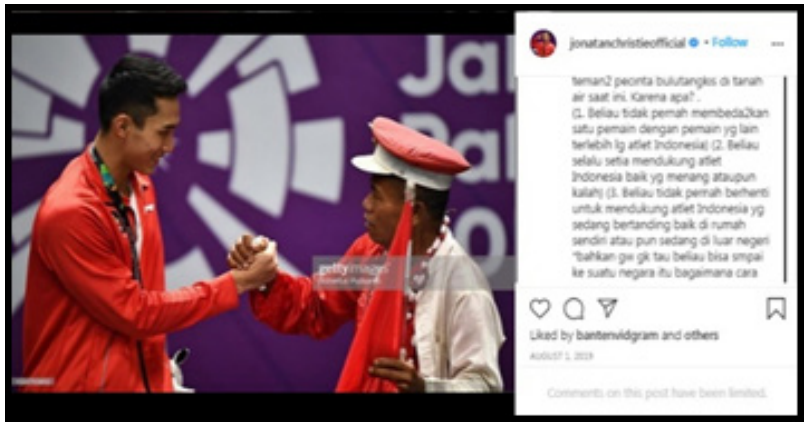

Gambar 3 Foto Haryanto dan Jojo Berjabat Tangan Sumber: Instagram Jojo (@jonatanchristieofficial) (2019)

digunakan adalah triangulasi. Triangulasi adalah pemeriksaan data dari berbagai sumber dengan berbagai cara, dan berbagai waktu. Ada tiga jenis triangulasi yaitu triangulasi sumber, triangulasi data dan triangulasi waktu. Sugiyono (2017). Trianggulasi yang digunakan dalam penelitian ini adalah trianggulasi data. Trianggulasi data dilakukan dengan memeriksa data kepada sumber yang sama dengan menggunakan teknik yang berbeda. Data dari satu sumber diperoleh dengan wawancara, observasi, dokumentasi.

\section{Hasil Penelitian dan Pembahasan Analisis Foto}

Peneliti melakukan analisa terhadap enam foto Haryanto yang beredar di media sosial.

Hasil analisis foto Haryanto Hormat Dengan Memegang Duplikat Piala Asia (Gambar 1). Representasi konseptual tidak ada vektor. Klasifikasi taksonomi tersembunyi, Haryanto dan piala memiliki posisi sama. Simbolik atributif, duplikat piala. Kontak, menawarkan tatapan mata mengarah pada kamera. Jarak Sosial, personal close up, foto diambil dalam jarak dekat hingga ekspresi Haryanto terlihat jelas. Sikap-subjektif-keterlibatan, jarak foto dekat. Posisi seimbang, khalayak dan objek pada foto memiliki posisi yang seimbang. Memusat, sirkular, pusat tanpa pinggiran, Haryanto fokus utama pada foto dengan tidak adanya

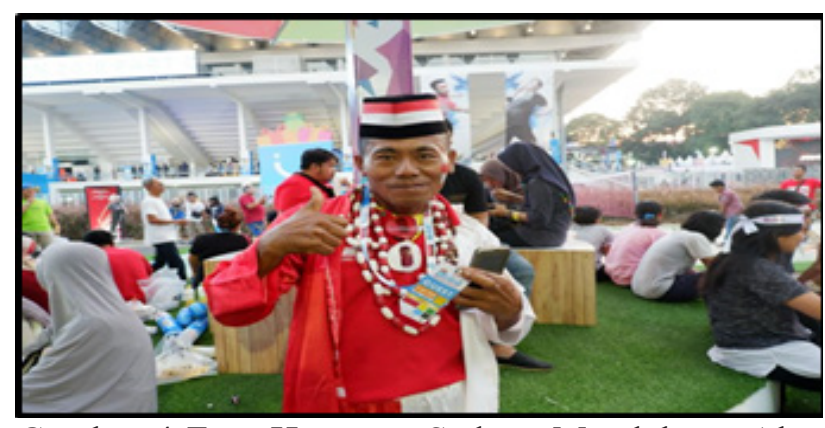

Gambar 4 Foto Haryanto Sedang Mendukung Altet Bulutangkis Indonesia

Sumber : https://www.blibli.com/friends/blog/yantosuporter-bulutangkis-indonesia/

pinggiran pada foto tersebut. Kemenonjolan maksimum, jarak foto close-up membuat foto menonjol secara maksimum. Bingkai maksimum terkoneksi, khalayak diajak ikut merasakan haru yang dirasakan oleh Haryanto.

Hasil Analisis Foto Haryanto Sedang Menabuh Genderang (Gambar 2). Representasi konseptual, tidak ada vektor. KlasifikasiTaksonomi Terbuka Level Ganda, Dalam foto terdapat banyak suporter dan memiliki perbedaan pada atribut yang mendukung para suporter tersebut. Simbolik-Sugestif, Foto memberi sugesti kepada khalayak untuk ikut bersemangat seperti Haryanto. Kontak, Menawarkan-Tatapan mata tidak kearah kamera. Jarak Sosial, Personal-Close up. Ekspresi Haryanto terlihat secara jelas. Sikap-SubjektifKeterlibatan, Khalayak diajak terlibat untuk semangat bersama Haryanto. Posisi Seimbang, Posisi Haryanto dalam foto dan khalayak sejajar. Memusat - Sirkular - Pusat Pinggiran, Haryanto sebagai pusat dengan adanya yang menjadi pinggiran dalam foto. KemenonjolanMaksimum, Jarak foto close up membuat kemenonjolannya terlihat jelas. BingkaiMaksimum Terkoneksi, Penonton yang masuk dalam frame terlibat sebagai latar foto Haryanto.

Hasil Analisis foto Haryanto dan Jojo Berjabat Tangan pada Gambar 3 Representasi naratif, tidak ada vektor. Vektor, mata saling 


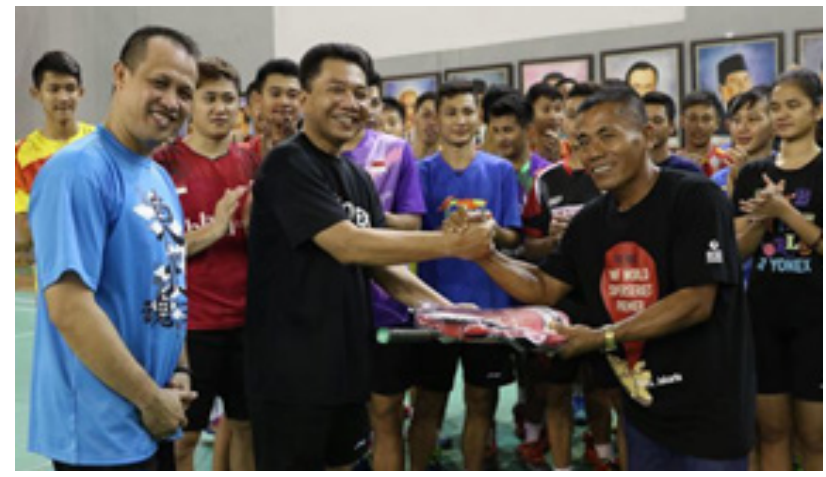

Gambar 5 Foto Haryanto Menerima Penghargaan Sumber: https://www.idntimes.com/hype/viral/ adiputra/10-potret-pak-yanto-suporter-bulu-tangkis-legendaris-selama-38-tahun/ 10

menatap dan jabatan tangan erat. Proses-agentifnon projektif, bukan foto yang menggambarkan siklus. Aksi transaksional searah, Haryanto dan Jojo saling menatap searah. Kontak, terus memberikan dukungan atau semangat kepada Jojo. Jarak Sosial, sosial-medium shot. Sikap subjektif keterlibatan, khalayak diajak terlibat dengan foto. Posisi seimbang, posisi khalayak dengan objek pada foto seimbang. Memusat sirkular, pusat tanpa pinggiran, Foto terpusat pada jabatan tangan yang dilakukan Haryanto dan Jojo tanpa adanya pinggiran. Kemenonjolan-Maksimum, Khalayak akan langsung terfokus pada Haryanto dan Jojo.

Hasil Analisis foto Haryanto sedang mendukung altet bulutangkis Indonesia. Representasi naratif, tidak ada vector. Vektor, tatapan mata Haryanto mengarah ke kamera. Agentif-non projektif, foto diatas bukan foto yang menampilkan siklus. Aksi-transaksionalsearah, Haryanto menjadi objek tunggal dan mengarah langsung ke kamera. Jarak Sosial, ekspresi Haryanto masih dapat ditangkap dengan sempurna. Kontak, meminta tatapan Haryanto lurus pada kamera. Sikap subjektif keterlibatan, tidak ditemukan. Posisi seimbang, posisi Haryanto dan khalayak seimbang. Memusat sirkular pusat tanpa pinggiran, Haryanto menjadi

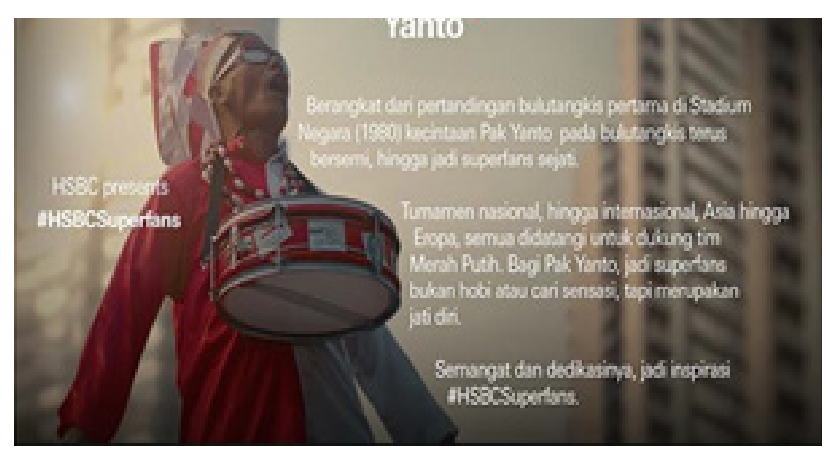

Gambar 6 Foto Haryanto

Menjadi Brand Ambassador HSBC

Sumber : https://www.hsbc.co.id/1/2/id/personal/ offers/kartu-kredit/offers/rayakan-juara-baru\#superfans

pusat dari foto, dengan tanpa pinggiran karena orang di sekitar Haryanto hanya menjadi latar. Kemenonjolan maksimum, jarak foto medium. Bingkai maksimum terkoneksi, orang yang berada di belakang Haryanto terpisah dari foto.

Hasil analisis foto Haryanto Menerima Penghargaan (Gambar 5). Representasi naratif, tidak ada vector. Vektor, jabat tangan erat. Proses agentif non projektif, bukan foto yang menggambarkan siklus. Aksi-transaksional searah, objek pada foto menatap searah pada kamera. Kontak, meminta mata menghadap kamera. Jarak sosial, Medium-close up. Jarak foto tidak terlalu jauh, namun ekspresi masih dapat terlihat. Sikap subjektif keterlibatan, atlet di sekitar Haryanto terlibat dalam foto sebagai bagian dari foto. Posisi Seimbang, posisi objek foto dan khalayak seimbang. Memusat sirkular-pusat pinggiran, khalayak akan terpusat pada jabatan tangan yang dilakukan. Foto memiliki pinggiran yang merupakan atlet yang terlibat dalam foto. Kemenonjolan maksimum, Jarak foto medium membuat foto ini memiliki kemenonjolan maksimum. Bingkaimaksimum terkoneksi, objek dan khalayak terkoneksi dalam foto. Khalayak diajak untuk ikut memberi selamat kepada Haryanto. 
Hasil analisis Foto Haryanto Menjadi Brand Ambassador HSBC (Gambar 6). Representasi konseptual, tidak ada vector. Simbolik-atributif, Haryanto terlihat mengenakan atribut merah putih yang menyimbolkan nasionalismenya. Haryanto terlihat mengenakan atribut merah putih yang menyimbolkan nasionalismenya. Kontak, menawarkan tatapan mata tidak melihat kamera. Jarak Sosial medium close up. Jarak pengambilan gambar tidak terlalu jauh. Sikap subjektif keterlibatan, foto memberi efek agar khalayak ikut terlibat dengan semangat Haryanto. Posisi seimbang, posisi objek dengan khalayak sama rata atau seimbang. Memusat sirkular-Pusat Tanpa Pinggiran. Fokus utama pada foto adalah Haryanto dengan tidak adanya pinggiran pada foto. Kemenonjolan maksimum foto mengesankan agar khalayak mau ikut mendukung para atlet seperti yang dilakukan oleh Haryanto. Bingkai-maksimum terkoneksi objek dan khalayak terkoneksi satu sama lain dengan melihat foto ini.

Atribut merah putih yang selalu dikenakan Haryanto bukan sekadar atribut untuk mendukung atlet bulutangkis Indonesia. Atribut merah putih sebagai perwujudan dari nasionalisme Haryanto. Atribut merah putih sebagai bukti kecintaan Haryanto pada Indonesia, yang ditunjukkan dalam setiap perhelatan bulutangkis yang diikuti oleh atlet asal Indonesia.

Gestur Haryanto yang selalu mengepalkan tangan sebagai wujud ekspresi mendukung atlet bulutangkis Indonesia. Haryanto memberikan sugesti positif bagi para atlet agar terus bersemangat dan memiliki jiwa nasionalis yang kuat seperti yang dimiliki oleh Haryanto.

Terdapat tiga elemen yang dapat membangun personalbranding. Elemen-elemen tersebutharus saling terintegrasi dan dibangun bersamaan. Tiga elemen personal branding yaitu You, Promise dan Relationship (Montoya \& Vandehey, 2008). Sedangkan pada semiotika sosial terdapat elemen yang sesuai dengan elemen personal branding, yaitu Aktor, Proses dan Sasaran. 1)
You dan Aktor: You pada personal branding dan aktor pada semiotika sosial memiliki kesamaan fungsi, yaitu sebagai orang yang menjadi pembuat tanda atau dalam bahasa personal branding adalah orang yang membangun brand. Aktor yang membangun personal brand pada penelitian ini adalah Haryanto. Haryanto menjadi aktor memiliki peran dalam membangun personal branding dirinya dengan cara membuat representasi nasionalisme yang melekat pada dirinya. Dengan nasionalismenya Haryanto membangun image untuk dirinya sendiri; 2) Promise dan Proses: Promise adalah janji, yang memiliki makna bahwa seorang yang sudah memiliki brand atas dirinya, harus bisa berjanji untuk tetap menjaga brand itu dengan baik. Untuk menjaga kepercayaan tersebut dibutuhkanlah proses. Proses ini bisa dilihat dari konsistensi Haryanto selalu menggunakan atribut berwarna merah putih setiap datang dipertandingan bulutangkis yang diikuti atlet atlet Indonesia. Hal tersebut dilakukan untuk membangun kepercayaan kepada khalayak luas. Haryanto itu bisa menjaga image dan brand yang telah terbentuk atas dirinya dengan baik; 3) Relationship dan Sasaran: Relationship merupakan hubungan dengan sasaran. Sasaran disini adalah masyarakat penonton pertandingan bulutangis atau orang-orang yang menjadi klien dari Haryanto. Haryanto dengan konsistensi mengkomunikasikan atribut merah putih sebagai ciri khasnya yang menjadi brand dirinya kepada orang-orang yang telah mengenal dirinya.

Peter Montoya (2002) berpendapat bahwa terdapat delapan konsep pembentukan Personal branding. Delapan konsep pembentukan Personal branding sebagai pondasi dari Personal Brand yang kuat, yaitu: 1) Spesialisasi (The law of specialization), Ciri khas dari sebuah personal brand yang hebat adalah ketepatan pada sebuah spesialisasi, terkonsentrasi hanya pada sebuah kekuatan, keahlian atau pencapaian tertentu. Pada elemen ini, Haryanto memiliki spesialisasi dimana dirinya adalah seorang suporter 
bulutangkis. Haryanto merupakan suporter yang memiliki ciri khas yang tidak dimiliki oleh orang lain. Itulah yang menjadi pembeda antara Haryanto dengan para suporter yang lainnya.

Haryanto yang selalu tampil di setiap pertandingan bulutangkis, dengan mengenakan atribut bersimbolkan Indonesia, membuatnya terkenal hingga kancah internasional pada dunia bulutangkis. Hanya dengan menjadi suporter, Haryanto telah berkeliling dunia untuk menonton pertandingan. Nasionalisme yang dimiliki Haryanto membuktikan bahwa dirinya dapat membuat brand sendiri.

Haryanto mengatakan atribut yang dipakai oleh dirinya agar dirinya dapat dilihat dan diperhatikan oleh orang lain. Selain sebagai perwujudan dari nasionalismenya yang sangat tinggi. Dengan memakai atribut merah putih Haryanto ingin menonjolkan dirinya.

2) Kepemimpinan (The Law of Leadership), personal brand yang dilengkapi dengan sosok pemimpin dapat memutuskan sesuatu dalam suasana penuh ketidakpastian dan memberikan suatu arahan jelas. Haryanto memiliki jiwa kepemimpinan yang tanpa disadari selalu muncul pada saat dirinya berada dalam kerumunan suporter bulutangkis. Ditandai dengan bagaimana Haryanto bisa mengajak satu tribun penonton untuk bersama dengannya meneriaki yel-yel untuk memberi dukungan kepada para atlet yang sedang berjuang di lapangan.

Haryanto menjadi leader dari para suporter bulutangkis yang sama-sama sedang mendukung atlet favoritnya bertanding. Jiwa pemimpin yang dimiliki Haryanto telah diakui, sehingga ketika Haryanto hadir dalam sebuah pertandingan bulutangkis, para suporter lain tidak akan segan untuk bergabung bersama Haryanto untuk mendukung atlet favorit mereka.

Tanpa adanya keinginan untuk dikenal, Haryanto dikenal oleh orang-orang dengan sendirinya. Seperti penggalan wawancara berikut ini: "Pokoknya kalau saya itu ya, awalnya tidak ada niat untuk dikenal. Cuma untuk bangsa dan negara itu tujuannya. Tapi lama kelamaan kok orang tahu semua" (Haryanto, 5 Agustus 2020)
3) Kepribadian (The Law of Personality), Personal brand yang hebat didasari dengan sosok kepribadian yang apa adanya dan hadir dengan ketidaksempurnaan. Konsep ini menghapuskan beberapa tekanan pada konsep kepemimpinan (the law of leadership). Seorang harus memiliki kepribadian yang baik, namun tidak harus sempurna.

Haryanto merupakan sosok yang ramah, humble, dan baik. Haryanto tidak merasa malu ketika dirinya hadir dalam satu pertandingan bulutangkis dengan mengenakan atribut yang terkesan berlebihan bagi beberapa orang. Haryanto tidak ambil pusing dengan hal itu. Haryanto tetap merasa percaya diri, karena nasionalisme sudah menjadi satu dengan dirinya, dengan mengenakan atribut lengkap seperti itulah dirinya menunjukkan nasionalismenya.

Haryanto tidak mengenakan atribut merah putih di luar arena pertandingan. Haryanto tetap dikenali dan disapa banyak orang mesti tanpa mengenakan atribut merah putih sebagai ciri khasnya. Diluar arena orang sering menyapa. Seperti penggalan wawacara berikut:

"Haryanto ya, kenapa tidak memakai pakaian lapangan Pak?, disuruh pakai." (Haryanto, 5 Agustus 2020)

4) Perbedaan (The Law of Distictiveness), personal brand yang efektif harus ditampilkan dengan cara yang berbeda dari yang lainnya. Diferensiasi diperlukan supaya membedakan antara satu dengan lainnya. Selain itu dengan perbedaan seorang akan lebih dikenal oleh khalayak. Yang membuat Haryanto berbeda adalah ciri khasnya. Haryanto mudah dikenali oleh sesama suporter bulutangkis dengan ciri khasnya. Ciri khas tersebut yang membuat personal branding-nya terbentuk dengan baik, sehingga image Haryanto belum bisa digantikan. Haryanto tidak tinggal di Indonesia tetapi jiwa dan raganya masih di Indonesia. Hal itu dibuktikan dengan kegigihannya untuk menjadi suporter bulutangkis dan menunjukkan nasionalisme dirinya kepada khalayak luas. 
Jika orang lain tampil berbeda agar ingin dikenal dan terkenal dan mendapatkan keuntungan. Apa yang dilakukan Haryanto semata mata sebagai bentuk dukungan terhadap bangsanya. Seperti kutipan wawancara berikut:

"Ya, kalau keuntungannya saya dikenal ya saya beruntung. Ada pula keuntungan saya dikenal, Cuma saya yang gak ingin terlalu bangga untuk itu. Pokoknya intinya berkaitan dengan bangsa gitulah." (Haryanto, 5 Agustus 2020)

5) Terlihat (The Law of Visibility), Personal brand harus dilihat secara konsisten dan terus menerus sampai personal brand seseorang dikenal. Maka visibilitylebih penting dariabilility . Supaya visible, seseorang perlu mempromosikan dirinya dan menggunakan setiap kesempatan untuk membuat dirinya terlihat. Personal brand yang terbentuk tanpa disengaja pada diri Haryanto selalu terlihat ketika dirinya sedang tampil di pertandingan bulutangkis menjadi suporter. Haryanto tetap menjaga image tersebut ketika dirinya diundang pada acara televisi ataupun dimintai wawancara oleh media massa.

Konsistensi yang dimiliki Haryanto telah bertahan lebih dari 36 tahun sejak pertama kali dirinya mulai menjadi suporter bulutangkis. Konsistensi tersebut membuat banyak orang yang ingin bertemu bahkan berfoto langsung dengan Haryanto ketika berlangsung perhelatan bulutangkis. Seperti kutipan wawancara berikut:

"Orang yang berebut mau foto sama saya. Dan juga kadang saya mau ketemu orang penting sampai kelewat." (Haryanto, 5 Agustus 2020)

6) Kesatuan (The Law of Unity), Kehidupan pribadi di balik personal brand harus sejalan dengan etika moral dan sikap yang telah ditentukan dari brand tersebut. Kehidupan pribadi selayaknya menjadi cerminan dan ciri yang diinginkan dalam personal branding. Haryanto yang sehari-harinya memiliki usaha di Malaysia tidak pernah kehilangan nasionalismenya. Haryanto rela merogoh kocek pribadinya untuk datang jauh-jauh ke Indonesia ataupun negara yang menyelenggarakan pertandingan bulutangkis yang diikuti oleh atlet Indonesia.
7) Keteguhan (The Law of Persistence), personal brand tidak bisa terjadi secara instan, membutuhkan waktu untuk tumbuh. Selama proses tersebut berjalan, penting untuk selalu memperhatikan tiap tahapan dan trand yang terjadi. Personal branding Haryanto tidak terbentuk dalam waktu singkat. Butuh waktu dan perjuangan panjang yang dilakukan oleh Haryanto, sehingga nasionalisme yang dimiliki olehnya ini dapat menjadi sebuah personal brand untuk dirinya sendiri. Sehingga ketika melihat dan atau mendengar nama Haryanto, yang terbesit dalam benak adalah suporter bulutangkis yang nasionalis, ditandai dengan atribut merah putih yang selalu dipakainya dalam setiap mendatangi turnamen bulutangkis yang diikuti oleh atlet Indonesia.

Keteguhan dan kegigihan Haryanto dalam menjadi suporter, membawa Haryanto dikenal sebagai individu yang memiliki nasionalisme dan kebanggaan yang luar biasa terhadap Indonesia. Haryanto telah dikenal oleh banyak orang yang mengagumi Haryanto atas kegigihannya menunjukan nasionalisme kepada masyarakat.

8) Nama Baik (The Law of Goodwill), sebuah personal brand akan memberikan hasil yang baik dan bertahan lebih lama jika seseorang dibelakangnya dipersepsikan dengan citra yang positif. Seseorang harus diasosiasikan dengan sebuah nilai atau ide yang diakui secara umum positif dan bermanfaat.

Nasionalisme yang ditunjukan Haryanto pada setiap pertandingan bulutangkis membuat nama Haryanto harum diantara para suporter bulutangkis Indonesia. Haryanto dikenal sebagai suporter yang berdedikasi tinggi dan juga memiliki kepribadian yang baik. Banyak orang yang sengaja datang ke pertandingan bulutangkis hanya untuk bertemu Haryanto. "Alhamdulillah, kalaudiJakartaitu, orang dari berbagai daerah di Indonesia, dari berbagai suku, ada banyak yang datang mau ketemu sama saya." (Haryanto, 5 Agustus 2020) Analisis semiotika sosial terhadap foto-foto Haryanto menunjukan representasi nasionalisme yang diperlihatkan Haryanto dalam memberi 
dukungan atlet bulutangkis Indonesia dapat membangun personal branding. Personal branding Haryanto sesuai dengan delapan elemen pembentukan personal branding Montoya. Haryanto memiliki tampilan atau ciri khas. Menjadi leader bagi suporter Indonesia, memiliki kepribadian yang kuat, tampilan yang berbeda, konsisten tidak berubah, teguh dalam pendirian, sikap yang baik dan citra yang positif.

Hal tersebut sejalan dengan penelitian Imawati A. V., Solihah A. W., Shihab M. (2016) Iin S. (2017), Afrilia A. M. (2018), bahwa strategi personal branding berhasil jika seseorang memiliki nilai, karakter, kekuatan, keahlian atau pencapaian tertentu. Memiliki keunggulan atau berfokus dibidang tertentu. Memiliki kepribadian yang kuat dan menonjol. Mampu memberikan kesan yang kuat dan berbeda dari yang lain. Dilakukan secara konsisten dan terus menerus supaya dikenal. Kehidupan pribadi sejalan dengan brand yang dibentuk. Memiliki keteguhan nilai dan perilaku, tidak berubah ubah, menjaga eksistensi dirinya. Citra diri positif, diterima, mendapat pengakuan dan membawa pengaruh positif. Selalu memelihara hubungan baik dalam keseharian maupun dalam media sosial.

Sesuai dengan teori representasi Haryanto mampu memproduksi makna melalui bahasa dan simbol yang ditampilkan. Simbol yang ditampilkan Haryanto tanpa disadari telah membentuk personal branding.

\section{Simpulan}

Brand merupakan pondasi awal yang sangat dibutuhkan ketika seseorang atau sebuah perusahaan ingin memperkenalkan dirinya kepada khalayak luas. Pembentukan sebuah brand membutuhkan usaha dan kerja keras.

Haryanto telah berhasil membangun personal brand. Haryanto dengan atribut merah putih telah berhasil membangun kepercayaan kepada orang yang belum dan telah mengenalnya. Dengan brand tersebut, Haryanto dapat berkelililing dunia untuk menonton pertandingan bulutangkis, dengan membawa nama Indonesia.
Pada tataran semiotika sosial, dari enam foto yang dianalisa, terdapat tiga foto yang merepresentasikan naratif dan tiga foto yang merepresentasikan konseptual. Setiap foto memiliki analisa yang berbeda dan menjadi satu kesatuan dalam merepresentasikan nasionalisme Haryanto.

Foto Haryanto mampu mewakili representasi nasionalisme yang dimilikinya. Dengan nasionalisme yang tinggi, Haryanto mampu membawa dirinya sampai ke kancah internasional dengan menjadi suporter bulutangkis yang dikenal berbagai negara. Haryanto telah mengharumkan nama Indonesia dengan menghadiri setiap pertandingan bulutangkis yang diikuti oleh atlet Indonesia.

Pada tataran personal branding, representasi nasionalisme yang ditunjukkan Haryanto telah membentuk personal branding dengan citra nasionalisme yang sudah melekat kuat pada dirinya. Nasionalisme diperlihatkan Haryanto dalam memberi dukungan atlet bulutangkis Indonesia setiap pertandingan mengenakan atribut merah putih. Analisis semiotika sosial yang digunakan untuk menganalisa foto-foto Haryanto, mampu memberikan gambaran representasi nasionalisme, yang membangun personal brand Haryanto.

Representasi nasionalisme sebagai personal branding Haryanto sesuai dengan delapan elemen pembentukan personal branding Peter Montoya. Nasionalisme Haryanto membuat dirinya punya personal brand. Elemen yang paling menonjol dalam personal branding adalah spesialisasi. Haryanto merupakan spesialis sebagai suporter bulutangkis dan suporter yang sangat nasionalis.

Secara teoritis hasil penelitian menunjukan personal branding dapat dibangun melalui representasi. Secara praktis hasil penelitian dapat digunakan sebagai dasar dalam membangun personal branding. Representasi dibentuk dengan menggunakan simbol simbol. Simbol-simbol yang digunakan harus dapat merepresentasikan delapan konsep personal branding Montoya. 


\section{Daftar Pustaka}

Afrilia, A. M., (2018), Personal Branding Remaja di Era Digital, Mediator: Jurnal Komunikasi, 11(1), 20-30. Agung, I. (2014). Pendidikan Wawasan Kebangsaan Di Daerah Perbatasan. Jakarta: Bee Media Pustaka.

Barker, C. (2008). Cultural Studies: Teori \& Praktik. Terj. Nurhadi. Yogyakarta: Kreasi Wacana. Bungin, B. (2008). Penelitian Kualitatif. Jakarta: Kencana Prenada Media Group. Butar, B. C. R., \& Ali, D. S. F., (2018) Strategi Personal Branding Selebgram Non Selebriti. Jurnal Ilmiah Ilmu Hubungan Masyarakat, 2(2), 86-101. Cabello, M. D., Gonzalez, B. JJ. (2003). Analysis of the Characteristics of Competitive Badminton. Br J Sports Med 37(1), 62-66 Chint, M. K., Wongt, A. SK., Sot, R. C.H., Siu, Oswald T., Steininger, K., and Los, D. T.L. (1995). Sport Specific Fitness Testing of Elite Badminton Players. Br. J. Sports Med., 29(3), 153-157 Denzin, N. K. dan Yvonna S. Lincoln(eds.). 2009. Handbook of Qualitative Research. Terj. Dariyatno dkk. Jogyakarta: Pustaka Pelajar. Dinata, M., T., H. (2004). Bulu Tangkis. Jakarta: Cerdas Jaya Eriyanto. (2019). Metode Komunikasi Visual. Bandung: PT. Remaja Rosdakarya. Hall, S. (2003). "The Work of Representation". Representation : Cultural Representation and Signifying Practices, ed. Stuart Hall. London Sage Publication. Hall, S. (2005). Culture, Media, Language. CCCS: Birmingham.

Hapsari I, W. I., (2015). Fanatisme dan Agresitivas Suporter Klub Sepak Bola. Jurnal Psikologi, 8(1), 53-58 Hasan Z. (2018). January 20). Media Asing sebut supporter Indonesia terbaik didunia. https://www.indosport.com/
Hasyim, I. (2020). January 18). Haryanto, Panglima Suporter Indonesia Masters 2020 dari Surabaya. https://www.indosport.com/ Hutchinson, J. and Smith, A. D., (ed). (2000). Nationalism: Critical Concepts in Political Science. London: Routledge Ibrahim, H., (2020). May 3) Suporter Bulutangkis Indonesia, Bagai Pisau Bermata Dua. https://www.indosport.com/ Imawati, A. V., Solihah, A. W., Shihab M. (2016). Analisis Personal Branding Fashion Blogger Diana Rikasari, JISIP: Jurnal Ilmu Sosial \& Ilmu Politik, 5(3), 175-184.

Indrayani H., Sunarto. (2019). Fandom: Strategi Komunikasi Pemasaran 3.0 Untuk Melanggengkan Fantasi Nasionalisme Melalui Olahraga. Jurnal Bricolage, 5(1), 15-30. DOI: http:// dx.doi.org/10.30813/bricolage.v5i01.1741 Junaedi, F. (2012). Bonek Suporter Pertama dan Terbesar di Indonesia, Yogyakarta: Buku Litera Kohn, H. (1984). Nasionalisme, Arti Dan Sejarahnya. Terj. Sumantri Mertodipuro. Jakarta: PT. Pembangunan. Moleong, L. J. (2012). Metodologi Penelitian Kualitatif. Cetakan ketigapuluhsatu Bandung: PT. Remaja Rosdakarya. Montoya, P. \& Vandehey. (2008). The Brand Called You: Make Your Business Stand Out in a Crowded Market place. United States of America: McGraw-Hill. Montoya, P. (2002), The Personal branding Phenomenon, Nashville: Vaughan Printing. Mulyana,D.(2010). MetodePenelitian Kualitatif: Paradigma baru ilmu komunikasi dan Ilmu Social. Bandung: PT Remaja Rosdakarya Rakhmad, J. (2009). Metode Penelitian Komunikasi.Bandung:PT.RemajaRosdakarya.

Salam, O. D. (2020) Personal Branding Digital Natives Di Era Komunikasi Media Baru (Analisis Personal Branding di Media Sosial). Jurnal BECOSS (Business Economic, Communication, and Social Sciences), 2(1), 19-30 
Salim,A. (2006). Teori dan Paradigma Penelitian Sosial. Yogyakarta: PT. Tiara Wacana. Siyoto S., dan Ali, S. (2015). Dasar Metodologi Penelitian. Yogyakarta: Literasi Media Publishing. Soraya, I. (2017). Personal Branding Laudya Cynthia Bella Melalui Instagram (Studi Deskriptif Kualitatif Pada Akun Instagram@Bandungmakuta). Jurnal Komunikasi, 8(2), 30-38. Sugiyono. (2017). Metode Penelitian Kuantitatif, Kualitatif, dan R\&D. Bandung: Alfabeta, CV.
Supriyanto, N. A., Rasyid, A. (2018) Analisis Karakterisitik Permainan Bulutangkis Tunggal Putra dan Tunggal Putri. Jurnal Pendidikan Jasmani dan Olahraga, 3(2), 167 - 171. DOI: 10.17509/jpjo.v3i2.11857 Wijaya,IM.K.(2018)Kecemasan,PercayaDiridan Motivasi Berprestasi Atlet UKM Bulutangkis. Jurnal Penjakora, 5(1), 36-46. DOI: http:// dx.doi.org/10.23887/penjakora.v5i1.14499 Yogi, G .P., Ruchiat, A., Setianti Y. (2016). Emergency Response Plan Garuda Indonesia. PRofesi Humas, 1(1), 65 - 77. 